\title{
Development of Basic Physics Experiment Textbooks Based on Pictorial Riddles
}

\author{
Apriani Sijabat*, Herna Febrianty Sianipar, Osco P. Sijabat, Theresia Monika \\ Siahaan, Christa Voni Roulina Sinaga \\ Pendidikan Fisika, Fakultas Keguruan dan Ilmu Pendidikan, Universitas HKBP, \\ Nommensen Pematangsiantar Jln. Sangnaauluh Pematangsiantar, Indonesia
}

\section{*Corresponding Author Email: aprianisijabat@gmail.com}

\section{Article History}

Received: April 2021

Accepted: May 2021

Published: June 2021

\section{Key Words}

Textbooks; basic physics experiments; pictorial riddles

How to cite this article?

\begin{abstract}
Basic physics experiment textbooks are widely used by lecturers and students in physics courses at universities, but relevant and easy-to-use basic physics experiment textbooks are not yet available. Most of the available books are practical books. The purpose of this study was to determine the stages of developing a basic physics experimental textbook based on pictorial riddles. This type of research is research and development (R\&D) research. The research uses the Plomp Model with three stages, namely preliminary research, prototype or development, and assessment. The subjects of this study were students of the Physics Education study program at the University of HKBP Nommensen Pematangsiantar. Data analysis used descriptive quantitative. The results showed that the development value of pictorial riddle-based textbooks had a high level of attractiveness based on the assessment of material/content experts reaching 93.75\%. The development value based on pictorial riddle has a high level of attractiveness based on field test assessments reaching 91\%. This shows that the development of pictorial riddle-based basic physics experimental textbooks has good quality and is suitable for use to improve student learning outcomes in basic physics experimental subjects.
\end{abstract}

Sijabat, A., Sianipar, H., Sijabat, O., Siahaan, T., \& Sinaga, C. (2021). Development of Basic Physics Experiment Textbooks Based on Pictorial Riddles. Lensa: Jurnal Kependidikan Fisika, 9(1), 38-44. doi:https://doi.org/10.33394/j-1kf.v9i1.3857

\section{INTRODUCTION}

The experimental basic physics course is one of the compulsory subjects in the physics education study program at HKBP Nommensen Pematangsiantar University. This course is a course with a weight of 2 credits. In general, basic physics experimental courses are subjects that carry out more practical work than theory. Students are required to be able to conduct experiments to prove the truth of the existing theory. To support the achievement of learning objectives for basic physics experimental subjects, supporting facilities are needed. One of the tools needed is the existence of a textbook as a guide for students in conducting experiments. Textbooks are one type of teaching material that can be developed. Textbooks are books that are compiled for the benefit of the learning process, whether sourced from research results or the results of an idea about something or a study of a particular field which is then formulated as learning material. (Arsyad, 2011).

Textbooks provide facilities for independent learning activities, both in terms of substance and presentation. The use of textbooks is part of the book culture, which is one of the signs of a developed society. Viewed from the learning process, textbooks have an important role (Andi, 2011). Textbooks are one of the important means to achieve the 
success of the learning process. The existence of textbooks will help students understand and master the goals to be achieved in the subjects they take. This book will guide and direct students in mastering the expected competencies in taking a subject. Books are a very fundamental learning medium. In learning, books not only act as a transfer of knowledge but also as a source of inspiration and motivation (Rizki M. 2015). According to observations made by researchers so far, the textbooks used in teaching basic physics experimental subjects at UHKBPNP are still in the form of practicum modules. So that students who carry out practicum are very difficult to experiment.

This is due to the fact that the modules used today are still lacking in containing learning materials regarding the basic introduction of tools and materials in practicum and the theories contained in the practicum module. The module currently used uses a work procedure whose steps are difficult for students to understand. Textbooks developed in lectures must be able to improve literacy and communication skills, namely textbooks that use pictures and direct experiments or known as pictorial riddles. Pictorial riddle is learning that uses pictures, experiments as a medium for problems in learning. So that the basic Physics Experiment lectures are easier to understand and apply by Physics education students. Pictorial riddle is a teaching strategy that can increase students' motivation and interest in small and large group discussions. Pictures, demonstrations, or materials presented based on perceived facts can be used as a way to improve students' critical and creative thinking. A riddle in the form of pictures, posters or direct experiments then the teacher asks questions about the riddle (Hamruni, 2009). Pictorial riddle is also a way of learning by confronting students with a problem to be solved or solved through pictures, demonstrations, or real situations (Depino, 2011). Therefore, researchers took the initiative to develop textbooks as an alternative to overcome these problems. The textbook that was developed is based on Pictorial riddles which can improve student learning outcomes in conducting physics experiments.

\section{METHOD}

The type of research used is $R \& D$ research. Research development is a process or steps to develop new products or improve existing products, and can be accounted for (Sukmadinata \& Syaodih. 2012). Research and development research is a research method to produce certain products (Sugiyono, 2010). Research activities are carried out to find out the initial or actual situation in the field as a problem in developing a product, namely the basic Physics Experiment textbook for Physics education students. The development model used is the Plomp model consisting of three stages, 1) preliminary research (initial investigation analysis), 2) prototyping or development phase (prototype or development stage), 3) assessment phase (assessment stage) (Plomp. 2013). The trial subjects at the Physics Education Study Program at HKBP Nommensen Pematangsiantar University were 15 people. The research data were obtained through analytical questionnaires, validation sheets, practicality, observation of attitudes, skills, and competency tests.

\section{RESULTS AND DISCUSSION}

The textbook produced in this development contains 3 stages, namely the Preminilary Research stage, the Prototyping or Development stage and the Assessment phase (the assessment stage/Field Test).

\section{Preliminary Research Stage}

The preliminary research stage is an initial analysis that aims to determine the need for developing Pictorial Riddle-Based Basic Physics textbooks for Physics Education Students. This stage is a guide in the development of textbooks so that they become more 
focused and of high quality. The results of the analysis of this stage were obtained by conducting a preliminary analysis, student analysis, and material analysis. Learning materials (instructional materials) are knowledge, skills and attitudes that must be mastered by students to fulfill learning outcomes in study program learning outcomes. The material analysis carried out in the development of pictorial riddle-based basic physics textbooks for physics education students are: Determining the Quantity of the Spring Constant; Determining the Coefficient of Fluid Volume Expansion; Dynamic Fluid Experiments; Hydrostatic Pressure; Flat Mirrors and Angle Mirrors; Refraction in Planparallel

\section{Prototyping or Development Stage}

The prototyping or development stage is the stage of designing and developing textbooks. The developed textbook consists of an introductory page, a core section, and a closing page (Rachmawati, 2004). The introductory page in the textbook consists of a book cover such as Figure 1.

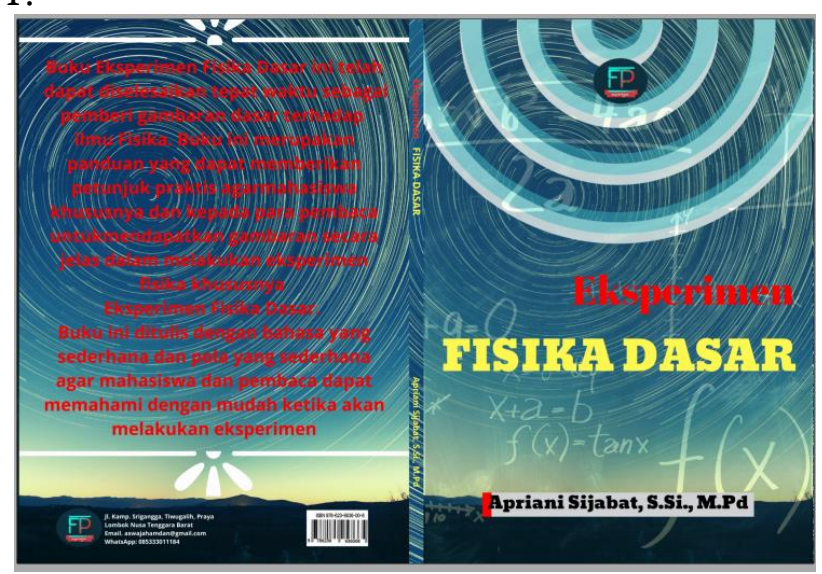

Figure 1. Cover of Basic Physics Experiments

Figure 1 describes the design of a textbook cover equipped with an ISBN number. The core part of the book consists of subtitles, material descriptions, sample questions, additional knowledge or the latest technology and practice questions related to the sub material being studied. As well as the closing pages of the required attachments, bibliography and author biodata.

\section{Assessment phase (Assessment phase/Field Test)}

After the preliminary research stage and the prototyping or development stage are carried out, the assessment stage or field test is carried out. The results of the field test were carried out by testing the use of basic physics experimental textbooks on 10 physics education students who taught basic physics experiments courses. The results obtained are that the average pre-test score is 47 and the post-test average is 81 . From these results, the post-test score is better than the pre-test score. So there is a difference before students use the developed textbook and after using the developed textbook.

The following is the presentation of the data from the validation of textbooks by material/content experts and media/design experts as well as supporting lecturers.

Table 1. Textbook Validation Results

\begin{tabular}{lllll}
\hline No & \multicolumn{1}{c}{ Aspects assessed } & Score & $\begin{array}{c}\text { Persentage } \\
(\mathbf{\%})\end{array}$ & Category \\
\hline I & FORMAT & & & \\
\hline & 1. Clarity of material distribution & 4 & 100 & Valid \\
& 2. Have Charm & 3 & 75 & Valid \\
\hline
\end{tabular}




\begin{tabular}{|c|c|c|c|c|}
\hline No & Aspects assessed & Score & $\begin{array}{l}\text { Persentage } \\
\quad(\%)\end{array}$ & Category \\
\hline & 3. Numbering system clear & 4 & 100 & Valid \\
\hline & 4. Room arrangement/ layout & 3 & 75 & Valid \\
\hline & 5. Match between text and illustrations & 3 & 75 & Valid \\
\hline & $\begin{array}{l}\text { 6. The type and size of the letters are } \\
\text { appropriate }\end{array}$ & 3 & 75 & Valid \\
\hline \multirow[t]{6}{*}{ II } & LANGUAGE & & & Valid \\
\hline & 1. Grammatical correctness & 3 & 75 & Valid \\
\hline & 2. Clarity of instructions/ & & 75 & Valid \\
\hline & directions,comments and problem solving & 3 & & \\
\hline & 3. Simplicity of sentence stucture & 3 & 75 & Valid \\
\hline & $\begin{array}{l}\text { 4. The communicative nature of the } \\
\text { language used }\end{array}$ & 3 & 75 & Valid \\
\hline \multirow[t]{4}{*}{ III } & ILLUSTRATION & & & \\
\hline & 1. Illustration Support & 3 & 75 & Valid \\
\hline & 2. Have a clear view & 4 & 100 & Valid \\
\hline & 3. Easy to understand & 3 & 75 & Valid \\
\hline \multirow[t]{6}{*}{ IV } & CONTENTS & & & \\
\hline & 1. Content / material truth & 4 & 100 & Valid \\
\hline & 2. Grouped into logical sections & 3 & 75 & Valid \\
\hline & 3. Suitability of material order & 4 & 100 & Valid \\
\hline & 4. Feasibility as a learning tool & 4 & 100 & Valid \\
\hline & Average & 3.41 & 83.82 & Valid \\
\hline
\end{tabular}

From Table 1 above, the average score for all textbook assessments is in the valid criteria, which is $83.82 \%$. The three validators concluded that the textbook could be used with minor revisions.

\section{Data Analysis of Textbook Content Expert Validation Results}

Based on Table 1, the results of the assessment given by the expert on validating the contents of the physics experiment textbook are valid. This is based on the development of textbooks produced by researchers that are relevant to the physics education curriculum. The overall score of the questionnaire assessment is presented as follows:

$$
P=\frac{\sum X}{\sum X i} x 100 \%=\frac{15}{16} x 100 \%=93.75 \%
$$

Where: $\sum X$ is the number of scores given by the validator

$\sum X i$ is the total maximum score for the content section

$\mathrm{P}$ is the percentage of assessment for the content of the textbook

The validation results from material experts/contents of physics experiment textbooks reached $93.75 \%$ and were in very valid criteria and did not need further revision. Textbooks are appropriate for the learning process.

\section{Data analysis of the results of the expert validation of Physics Experiment Textbook Design}

The results of the assessment given by the textbook design validation expert are sufficient. This is based on the development of basic physics experiment textbooks that the textbook appearance is quite attractive and suitable for use in learning.

The overall score of the questionnaire assessment is presented as follows: 


$$
P=\frac{\sum X}{\sum X i} x 100 \%=\frac{43}{52} x 100 \%=82.6 \%
$$

Where : $\sum X$ is the number of scores given by the validator for the Format, Language and Illustration section (Design Section)

$\sum X i$ is the total maximum score for the Format, Language and Illustration section (Design Section)

$\mathrm{P}$ is the percentage rating for the Format, Language and Illustration section (Design Section)

The validation results from the physics experiment textbook design expert reached $82.6 \%$ and were in very valid criteria and did not need further revision. Textbooks are appropriate for the learning process.

\section{Data Analysis of Field Trial Results of Basic Physics Experiment Textbooks}

Data analysis of the results of field tests conducted on students aims to determine the extent to which students' abilities in mastering basic physics experimental learning materials during lectures on the ability of knowledge, attitudes, and skills.

Knowledge ability

Knowledge ability aims to determine the extent to which students' ability to understand the material during lectures with an average of 81 is categorized as good, but still needs more understanding to relate basic physics experimental material in everyday life.

Attitude Ability

Attitude competence in learning is a series of activities designed to measure the values or views of life obtained by students as a result of a learning program.

Skill Competence

Skill abilities are educators assessing practice tests, projects and portfolio assessments (Prastowo, 2011).

Table 2. Table of Field Test Results

\begin{tabular}{|c|c|c|c|c|c|c|c|c|c|c|c|c|c|}
\hline \multirow{2}{*}{$\begin{array}{c}\text { No Subject } \\
\text { ( College student) }\end{array}$} & \multicolumn{13}{|c|}{ Assessment Aspect } \\
\hline & 1 & 2 & 3 & 4 & 5 & 6 & 7 & 8 & 9 & 10 & $\Sigma \mathbf{N}$ & $\Sigma x i$ & $\%$ \\
\hline 1 & 4 & 4 & 4 & 4 & 4 & 4 & 4 & 4 & 3 & 3 & 38 & 40 & 95 \\
\hline 2 & 3 & 4 & 4 & 4 & 4 & 3 & 4 & 4 & 3 & 3 & 38 & 40 & 95 \\
\hline 3 & 4 & 4 & 4 & 4 & 4 & 4 & 4 & 3 & 4 & 4 & 39 & 40 & 97.5 \\
\hline 4 & 4 & 4 & 3 & 3 & 3 & 3 & 3 & 4 & 4 & 4 & 35 & 40 & 87.5 \\
\hline 5 & 3 & 4 & 4 & 4 & 4 & 4 & 4 & 4 & 3 & 3 & 37 & 40 & 92.5 \\
\hline 6 & 3 & 4 & 3 & 4 & 4 & 3 & 4 & 3 & 4 & 4 & 36 & 40 & 90 \\
\hline 7 & 4 & 4 & 3 & 4 & 4 & 3 & 3 & 4 & 3 & 4 & 36 & 40 & 90 \\
\hline 8 & 4 & 3 & 3 & 3 & 3 & 4 & 4 & 4 & 4 & 4 & 36 & 40 & 90 \\
\hline 9 & 3 & 4 & 3 & 3 & 4 & 3 & 4 & 3 & 4 & 4 & 35 & 40 & 87.5 \\
\hline 10 & 3 & 4 & 4 & 3 & 4 & 3 & 4 & 3 & 3 & 3 & 34 & 40 & 85 \\
\hline Average & & & & & & & & & & & & & 91 \\
\hline
\end{tabular}

Information:

Assessment aspect 1: The physics experiment textbook that was developed can facilitate learning

Assessment aspect 2: The use of physics experiment textbooks can encourage learning memberi

Assessment aspect 3: the subject matter contained in the physics experiment textbook is easy to understand 
Assessment aspect 4: The practical guide contained in the physics experiment textbook is easy to practice

Assessment aspect 5: the typeface and font size contained in the basic physics experiment textbook is very easy to read

Assessment aspect 6: In studying this book, I did not find difficult words

Assessment aspect 7: the instructions contained in the textbook are very easy to understand

Assessment aspect 8: the language contained in the basic physics experiment textbook is easy to understand

Assessment aspect 9: Practice questions are easy to understand

Assessment aspect 10: Basic physics experiment textbooks can help to work together in teams

Subject No (1-10): Student Respondents who use basic physics experiment textbooks

$\mathrm{Xi}$ : The number of ideal scores in one item

$\mathrm{N}$ : Total score of each respondent

xi : Total score of all items' ideal score

Based on Table 2, the results of the field trial assessment can be described as follows: The results of the field trial validation of physics experiment textbooks reached $91 \%$ and were in the valid criteria and did not need further revision. Textbooks are appropriate for the learning process.

\section{CONCLUSION}

Based on the results and discussion, it can be concluded that the development of this pictorial riddle-based textbook resulted in a product in the form of a basic physics experiment textbook. The product developed has fulfilled the components as a good textbook and can be used in the learning process. The feasibility of a pictorial riddle-based physics experiment textbook obtained a percentage value from the experts and subjects studied as follows:

1. The post-test score reached an average of 81 compared to the average pretest score of 47, there was a significant increase. This shows that there is an increase in learning outcomes after using the product development of the basic physics experimental textbook based on pictorial riddles.

2. The value of developing a pictorial riddle-based textbook has a high level of interest based on the assessment of material/content experts reaching $93.75 \%$

3. The acquisition value of pictorial riddle-based development has a high level of attractiveness based on the assessment of design experts reaching $82.6 \%$

4. The acquisition of a pictorial riddle-based development score has a high level of attractiveness based on a field test assessment of $91 \%$.

Thus the development of pictorial riddle-based physics experimental textbooks can be said to have good quality. This is because the use of this textbook can increase the effectiveness and feasibility and provide a positive influence in improving student learning outcomes

\section{RECOMMENTATION}

The suggestion for further researchers is to be able to develop other textbooks according to their field of science based on pictorial riddles. 


\section{ACKNOWLEDGMENT}

The author would like to appreciation to the Institute for Research and Community Service (LPPM) University of HKBP NommensenPematangsiantarwho has supported this research, it can be carried out well and all participant who support and helptocompleted this article.

\section{REFERENCES}

Azhar, A. (2011). Media Pembelajaran. Jakarta: PT. Raja Grafindo Persada.

Depino, P. (2011). Yale-New Haven Teachers Institute: A Creative Classroom Model for a Sixth Grade Science Class.

Elliot, S., N. (2000). Educational Psycology: Effective teaching, Effective learning. 3 rd Ed. Boston: McGraw - Hill

Fatkhurrohman, M.A \& Astuti, R.K. (2017). Pengembangan Modul Fisika Dasar I Berbasis Literasi Sains. Jurnal Pancasakti Science Education Journal PSEJ. 2(2):63-171.

Hamruni. (2009). Strategi dan Model- Model Pembelajaran Aktif Menyenangkan. Yogyakarta: Fakultas Tarbiyah UIN Sunan Kalijaga.

Junaidi, S.N. \& Asra, A. (2019). Pengembangan Buku Ajar Fisika Dasar Berbasis Pictorial Riddle Untuk Mahasiswa Pendidikan Biologi. Diffraction: Journal for Physics Education and Apllied Physics. Vol.1 No.2: 2685-7723.

Permana, F.H. (2015). Pengembangan Buku Ajar Biologi Berbasis Blended Learning Sebagai Bekal Hidup Di Abad 21 Untuk Mahasiswa S1 Kimia FMIPA UM. Prosiding Seminar Nasional Pendidikan Biologi 2015. Malang: Universitas Muhammadiyah Malang.

Plomp, T. (2013). Educational and Training System Design. Enschede. Netherlands: Univercity of Twente.

Prastowo, A. (2011). Panduan Kreatif Membuat Bahan Ajar Inovatif. Yogjakarata: Diva press

Rachmawati W.S. (2004). Anatomi Buku Ajar. Departemen Pendidikan Nasional. Jakarta.

Riduwan. (2009). Belajar Mudah Penelitian untuk Guru, Karyawan, dan Peneliti Pemula. Bandung: Alfabeta.

R. Maulida and M. P. Simanjutak. (2015). Pengembangan Bahan Ajar Fisika SMA Berbasis Investigasi pada Materi Fluida Dinamis Untuk Meningkatkan Hasil Belajar Siswa, Jurnal Pendidikan Fisika, 4(1), 71-76.

Sugiyono. (2012). Metode Penelitian Pendidikan. Bandung: Alfabeta.

Sukmadinata \& Nana Syaodih. (2012). Metode Penelitian Pendidikan. Bandung: Remaja Rosdakarya.

Viera, A.J \& Garret, J.M. (2005). Understanding Interobserver Agreement the Kappa Statistic. Research. Journal Research Series Vol.37 No.5 